\title{
HUBUNGAN USIA KEHAMILAN DAN KADAR HB TERHADAP TINGKAT BBL DI RSUD IBNU SINA KABUPATEN GRESIK
}

\section{Correlation Between Gestational Age and Hemoglobin Levels with Birth Weight in the Regional General Hospital Ibnu Sina District Gresik}

\author{
Sri Eka Purwanengsi \\ Program Studi Kebidanan STIKES Datu Kamanre Belopa \\ (srieka144@gmail.com)
}

\begin{abstract}
ABSTRAK
Berat badan lahir merupakan indikator kesehatan bayi maka harus ditanggani dengan baik, terutama pada bayi yang lahir dengan berat rendah karena dapat berdampak pada kelangsungan hidup bayi. Kasus BBLR ini disebabkan oleh berbagai faktor diantaranya faktor ibu misalnya usia kehamilan dan kurangnya suplai gizi sehingga berpengaruh terhadap kadar HB ibu hamil. Tujuannya untuk mengetahui hubungan usia kehamilan dan kadar HB ibu terhadap tingkat berat badan lahir. Jenis penelitian adalah Non Reactive yang dilaksanakan di RSUD ibnu sina Kabupaten Gresik pada bulan Februari-Juli 2017. Penelitian ini menggunakan sampel 123 dari 928 persalinan dengan metode pengambilan sampel simple random sampling. Data dianalisis menggunakan uji chi-square pada program SPSS. Hasil penelitian menunjukkan bahwa terdapat hubungan yang signifikan antara usia kehamilan dan kadar HB terhadap tingkat berat badan lahir, dimana usia kehamilan diperoleh P-value $0.000<\alpha(0.05)$ dan kadar HB diperoleh P-value $0.000<\alpha(0.05)$. Oleh karena itu, perlu adanya pemberian informasi tentang faktor resiko penyebab BBLR khususnya usia kehamilan dan kadar HB.
\end{abstract}

Kata Kunci: Berat badan lahir, usia kehamilan, dan kadar hemoglobin

\section{ABSTRACT}

Birth weight is an indicator of infant health then needs to be handled properly, especially in low birth weight babies because it can affect the survival of infants. The case of Weight Infant Low Birth is caused by various factors such as maternal factors such as gestational age and less of nutrition supply so that it affects hemoglobin concentration of pregnant women. The purpose is know the relationship between gestational age and maternal hemoglobin level to birth weight. The type of this research is Non Reactive which implemented in RSUD ibnu sina Gresik Regency in February-July 2017. This study use sample 123 from 928 labor with by using simple random sampling method. Data were analyzed using chi-square test in SPSS program. The results of the study showed there was a significant correlation relationship between gestational age and $H B$ level to birth weight level, where gestational age was obtained $P$-value $0.000<\alpha(0.05)$ and $H B$ level was obtained $P$-value $0.000<\alpha$ (0.05). Therefore, it is necessary to provide information on risk factors for Weight Infant Low Birth, especially gestational age and hemoglobin levels.

Keywords: Birth weight, gestational age and hemoglobin level 


\section{PENDAHULUAN}

Angka kematian bayi merupakan cermin dari derajat kesehatan masyarakat. Untuk itu, langkah utama untuk menyelamatkan bayi baru lahir dengan berat rendah agar dapat tumbuh dan berkembang dengan baik adalah melalui deteksi dini pada bayi baru lahir yang di ikuti dengan upaya tindak lanjut tepat sasaran. ${ }^{1}$ Berat Badan Bayi Lahir Rendah (BBLR) merupakan faktor utama dalam peningkatan mortalitas, morbiditas dan disabilitas neonatus, bayi dan anak serta memberikan dampak jangka panjang terhadap kehidupannya di masa depan. $^{2}$

Data WHO dan UNICEF tahun 2013 menunjukkan bahwa terdapat $16 \%$ bayi lahir dengan berat badan lahir rendah dari 22 juta bayi yang dilahirkan di dunia. Persentase BBLR di negara berkembang adalah 16,5\% dua kali lebih besar dari pada negara maju (7\%). Indonesia adalah salah satu negara berkembang yang menempati urutan ketiga sebagai negara dengan prevalensi BBLR tertinggi $(11,1 \%)$, setelah India $(27,6 \%)$ dan Afrika Selatan (13,2\%). Selain itu, Indonesia turut menjadi negara ke dua dengan prevalensi BBLR tertinggi diantara negara ASEAN lainnya, setelah Filipina (21,2\%).

Data Survei Demografi dan Kesehatan Indonesia (SDKI) Tahun 2007 angka kematian neonatal sebesar 19 kematian per 1000 kelahiran. Survei Demografi Kesehatan Indonesia (SDKI) pada tahun 2012 didapatkan angka kematian neonatal sebesar 19 kematian per 1000 kelahiran. Hal ini menunjukan bahwa angka kematian yang terjadi pada masa neonatal tidak mengalami penurunan dan angka tersebut lebih besar dari target Milennium Development Goals (MDGs) yaitu angka kematian neonatal sebesar 14 kematian per 1000 kelahiran.

Hasil Riskesdas 2013 diketahui bahwa persentase BBLR di Indonesia pada tahun $2013(10,2 \%)$ lebih rendah dari tahun 2010 $(11,1 \%)$ tetapi angka ini lebih besar dari target BBLR yang ditetapkan pada sasaran program gizi menuju Indonesia sehat 2010 yakni maksimal tujuh persen (Pantiawati, 2010). Hasil Badan Litbangkes dalam Profil Kesehatan Indonesia 2013 diketahui bahwa persentase kasus berat badan lahir rendah (BBLR) <2500 gram pada balita (0-59 bulan) provinsi Jawa Timur berada pada urutan 11 dari 33 provinsi yang ada di Indonesia yaitu sebesar $11,2 \%$ dan angka ini lebih tinggi dari tahun $2010 .^{3}$

Berdasarkan Profil Kesehatan Provinsi Jawa Timur tahun 2010 diketahui bahwa jumlah BBLR di kabupaten Gresik sebesar 389 kasus dari 18.830 kelahiran hidup. Data dari RSUD Ibnu Sina kabupaten Gresik tahun 2015 diketahui bahwa jumlah BBLR sebesar 253 kasus dari 928 persalinan. Data tersebut menunjukkan bahwa kasus BBLR di RSUD Ibnu Sina kabupaten Gresik masih cukup tinggi, sehingga masalah bayi BBLR penting untuk diperhatikan karena sangat erat 
kaitannya dengan kelangsungan hidup bayi tersebut. $^{4}$

\section{BAHAN DAN METODE}

Jenis penelitian yang digunakan adalah penelitian Non Reactive (unobstructive) yang merupakan data sekunder yang dikumpulkan oleh tenaga kesehatan berupa dokumen yang ada di rekam medik rumah sakit. Penelitian ini dilaksanakan di rumah sakit umum daerah (RSUD) Ibnu Sina kabupaten Gresik dan waktu pelaksanaan penelitian dari bulan Februari-Juli 2017. Populasi dalam penelitian ini adalah seluruh ibu yang melahirkan di RSUD ibu persalinan pada tahun 2015 yaitu 928 persalinan dan sampel yang digunakan adalah 123 ibu. Teknik pengambilan sampel menggunakan simple random sampling. Analisis yang digunakan adalah analisis univariat dan bivariat dengan menggunakan uji chi-square yang disajikan dalam bentuk distribusi frekuensi disertai penjelasan berdasarkan data pada tabel distribusi frekuensi.

\section{HASIL}

Hasil penelitian ini diperoleh bahwa persentase ibu melahirkan mempunyai berat bayi lahir kurang sama dengan 1500 gram sebesar 8,1 persen, berat bayi lahir antara 1500 - <2500 gram sebesar 20,3 persen dan berat bayi lahir $\geq 2500$ gram sebesar 71,5 persen. Hal ini menunjukkan bahwa sebagian besar ibu melahirkan mempunyai lebih dari 2500 gram. Untuk persentase usia kehamilan saat melahirkan kurang sama dengan 37 minggu sebesar 43,9 persen, dan usia kehamilan saat melahirkan lebih dari 37 minggu sebesar 56,1 persen sedangkan persentase ibu yang mempunyai kadar HB kurang sama dengan 7 g/dl sebesar 4,9 persen, kadar HB dari >7 g/dl $<11$ g/dl sebesar 42,3 persen dan kadar HB lebih sama dengan $11 \mathrm{~g} / \mathrm{dl}$ sebesar 52,8 persen. Hal ini menunjukkan bahwa sebagian besar Usia Kehamilan saat melahirkan lebih dari 37 minggu dan mempunyai kadar HB lebih dari sama dengan $11 \mathrm{~g} / \mathrm{dl}$.

Hasil analisis bivariat menunjukkan bahwa nilai Chi-Square $=15.468$ (P-value 0.000) lebih besar dari Chi-Square Tabel $\chi_{(0.05 ; 2)}^{2}=5.991$. Dengan tingkat signifikan 95\% diperoleh keputusan bahwa terdapat hubungan antara Usia Kehamilan saat melahirkan dengan Berat Bayi Lahir sedangkan kadar HB diperoleh nilai ChiSquare $=24.339(\mathrm{P}$-value 0.000$)$ lebih besar dari Chi-Square Tabel $=\chi_{(0.05 ; 4)}^{2}=9.488$ sehingga diperoleh keputusan bahwa terdapat hubungan antara Kadar HB dengan Berat Bayi Lahir.

\section{PEMBAHASAN}

Hasil penelitian secara univariat didapatkan bahwa usia kehamilan mempunyai pengaruh yang signifikan terhadap variabel tingkat berat badan lahir dengan nilai P-value 0.000 dimana nilai P-value lebih kecil dari alfa 0,05 yang berarti usia kehamilan signifikan atau mempengaruhi tingkat berat badan lahir. 
Hal ini tidak sejalan dengan penelitian yang dilakukan oleh Sulistyorini (2015) yang menyataka bahwa tidak terdapat hubungan yang signifikan antara usia kehamilan dengan berat badan bayi lahir rendah $^{5}$ akan tetapi sejalan dengan penelitian yang dilakukan oleh Fanni (2017) di Surabaya yang menunjukkan ada hubungan antara usia kehamilan ibu dengan berat badan bayi yang mengatakan bahwa ibu dengan usia gestasi yang tergolong awal memiliki kecenderungan untuk melahirkan bayi BBLR dengan risiko 4 kali lebih besar dibanding ibu dengan usia gestasi yang tergolong penuh. ${ }^{6}$

Umur kehamilan adalah jumlah minggu lengkap dari hari pertama mensturasi terakhir sampai anak lahir. Faktor umur kehamilan mempengaruhi kejadian BBLR, karena semakin pendek umur kelahiran semakin kurang sempurna pertumbuhan alat-alat tubuhnya, sehingga turut mempengaruhi berat badan waktu lahir. ${ }^{7}$

Hasil penelitian secara parsial didapatkan bahwa kadar $\mathrm{Hb}$ mempunyai pengaruh yang signifikan terhadap variabel tingkat berat badan lahir dengan nilai P-value 0.000, dimana nilai P-value lebih kecil dari alfa 0,05 yang berarti kadar $\mathrm{Hb}$ signifikan atau mempengaruhi tingkat berat badan lahir. Hal ini sejalan dengan penelitian yang dilakukan oleh Lia (2011) menunjukkan bahwa ibu memiliki kadar $\mathrm{Hb}<11$ gr/dl beresiko sebesar 4,643 kali untuk melahirkan bayi dengan berat badan lahir rendah dibandingkan ibu yang memiliki kadar $\mathrm{Hb} \geq 11 \mathrm{gr} / \mathrm{dl} .{ }^{8}$ Demikian pula pada penelitian Sandra 2013 tentang faktorfaktor resiko kejadian berat badan lahir rendah di wilayah kerja unit pelayanan terpadu kesehatan masyarakat Gianyar II yang menyatakan bahwa peluang terjadinya BBLR pada kadar $\mathrm{Hb}<11$ sebesar 23,385 kali lebih besar dibandingkan kadar $\mathrm{Hb}>11$.

Hemoglobin $(\mathrm{Hb})$ yaitu komponen sel darah merah yang berfungsi menyalurkan oksigen ke seluruh tubuh, jika kadar $\mathrm{Hb}$ berkurang maka jaringan tubuh kekurangan oksigen dimana oksigen sebgai bahan bakar untuk proses metabolisme. Untuk itu, kadar $\mathrm{Hb}$ ibu hamil sangat mempengaruhi berat bayi yang dilahirkan. Hal ini dapat menimbulakan gangguan pertumbuahan hasil konsepsi, sering terjadi immanuritas, prematuritas, cacat bawaan, atau janin lahir dengan berat badan lahir rendah karena kurangnya suplai oksigen dan nutrisi pada plasenta yang akan berpengaruh pada fungsi plasenta terhadap pertumbuhan janin?

\section{KESIMPULAN DAN SARAN}

Hasil analisis dan pembahasan dalam penelitian ini, dapat ditarik kesimpulan bahwa usia kehamilan saat melahirkan dan kadar HB mempunyai hubungan yang signifikan terhadap variabel tingkat berat badan lahir di RSUD Ibnu Sina kabupaten Gresik. Dalam menurunkan angka kematian bayi perlunya peningkatan pembinaan dan pemberian informasi secara aktual tentang faktor resiko 
penyebab BBLR khususnya usia kehamilan dan pentingnya pemeriksaan kadar HB dan perlu dilakukan penelitian lanjutan terkait dengan faktor-faktor lain yang mempengaruhi tingkat berat badan lahir.

\section{DAFTAR PUSTAKA}

1. Budihardja. Pedoman Pelayanan Antenatal Terpadu. Jakarta: Kementerian Kesehatan Direktorat Jenderal Bina Kesehatan Masyarakat Direktorat Bina Kesehatan Ibu, Kementerian Kesehatan RI; 2010.

2. Proverawati, A dan Ismawati, C. Bayi Berat Lahir Rendah. Yogyakarta: Nuha Medika; 2010.

3. Badan Penelitian dan Pengembangan Kesehatan. Riset Kesehatan Dasar (RISKESDAS 2013). Jakarta: Kementerian Kesehatan RI ; 2013.

4. Dinas Kesehatan Provinsi Jawa Timur. Profil Kesehatan Povinsi Jawa Timur Tahun 2012. Surabaya: Dinas Kesehatan Provinsi Jawa Timur; 2013.

5. Sulistyorini, D. Analisis FaktorFaktor yang Mempengaruhi Kejadian BBLR di Puskesmas Pedesaan Kabupaten Banjarnegara Tahun 2014. Semarang: Universitas Diponegoro. [Serial Online]. 2015. [Diakses 6 Mei 2017]. Available at: http://www.polibara.ac.id/wp-
content/uploads/2015/04/Dewie-

Sulistyorini.pdf.

6. Fanni DRY, Adriani M. Hubungan Usia Gestasi dan Kadar Hemoglobin Trimester 3 Kehamilan dengan Berat Lahir Bayi. Surabaya : Jurnal Amerta Nutrition. [Serial Online]. 2017. [Diakses 6 Mei 2017]. Available at: https://e-

journal.unair.ac.id/AMNT/article/view /6241.

7. Manuaba I.B.G. Ilmu Kebidanan dan Penyakit Kandungan dan Keluarga Berencana untuk Pendidikan Bidan. Jakarta: EGC; 1998.

8. Lia A. Faktor Resiko Kejadian Bayi Berat Lahir Rendah (BBLR) di RSU Dr. MM Dunda Limboto Kabupaten Gorontalo volume 6 No.3. Jurnal Saintek. Gorontalo: Universitas Negeri Gorontalo; 2011.

9. Depkes RI. Profil Kesehatan Indonesia 2008. Jakarta: Pencatatan Negara [Serial Online]. 2009. [Diakses 10 Maret 2017]. Available at: $\underline{\text { www.depkes.go.id }}$

10. Depkes RI. Modul Tetanus Neonatorium dan BBLR. Jakarta : Pencatatan Negara; 2002.

11. Kuntoro. Metode Sampling dan Penentuan Besar Sampel. Surabaya: Pustaka Melati; 2010. 
12. Prawirohardjo, S. Ilmu Kebidanan. Jakarta : P.T. Bina Pustaka Sarwono Prawirohardjo. 2002.

13. Setyowati, T. Faktor - Faktor yang Mempengaruhi Bayi Lahir dengan Berat Badan Lahir Rendah (Analisa data SDKI 1994) Vol. 24 No $2 \& 3$. Jurnal Badan Litbang Kesehatan. [Serial Online]. 1996. [Diakses 10 Juni 1996]. Available at: www. jkpkbppk-gdl-res-1996-titiek-1137bayi.com.

14. Sulaiman, Z. Beberapa Faktor Resiko Wanita Pada Wanita Hamil. Cipanas: Hasil Seminar Ilmu Pengetahuan Dan
Teknologi (IPTEK) Gizi dan Kesehatan Ibu Hamil. 1986.

15. Surya. R.S. Faktor - Faktor Risiko Kejadian Berat Bayi Lahir Rendah Di Wilayah Kerja Unit Pelayanan Terpadu Kesmas Gianyar II. vol. 4 no. 4. E-jurnal medika udayana, Fakultas Kedokteran Universitas Udayana. [Serial Online]. 2013. [Diakses 6 Mei 2017]. Available at: https://ojs.unud.ac.id/index.php/eum/articl e/view/13057.

16. Susanti E. Prinsip Dasar Perawatan Bayi Berat Lahir Rendah. Sidoardjo: Quality Development. 2011. 